\title{
ALIENASI REMAJA DARI LINGKUNGAN SOSIAL (TELAAH KRITIS PADA GENERASI MUDA PECINTA GAME ONLINE )
}

\author{
Rahman Malik ${ }^{1}$, Achmad Hidir ${ }^{2}$ dan Himmiyatul Amanah ${ }^{3}$ \\ ${ }^{1}$ Program Studi Sosiologi, Fakultas IImu Sosial dan IImu Politik, Universitas Sumatera Utara, \\ Medan, Sumatera Utara. \\ ${ }^{2}$ Program Studi Sosiologi, Fakultas IImu Sosial dan IImu Politik, Universitas Riau, Pekanbaru, \\ Riau. \\ ${ }^{3}$ Sosiologi, Madrasah Aliyah Negeri 1 Jembrana, Bali. \\ Email: rmalik20@usu.ac.id, 2achmad.hidir@lecturer.unri.ac.id, \\ 3himmiyatulamanah@gmail.com
}

\begin{abstract}
Abstrak
Perkembangan internet yang semakin maju merupakan awal dari tumbuhnya game online dikalangan remaja. Bahkan bisa menjadi media yang sangat menghibur dan bisa menjadi bagian dari representasi identitas seseorang. Terlebih lagi di era sekarang ini, fenomena remaja yang menjadi penerus bangsa sudah mulai kehilangan kendali diri akibat game online. Tujuan dari penelitian ini adalah untuk melihat secara kritis dampak merugikan dari game online yang mampu mengasingkan remaja dari lingkungan sosial dan keluarganya. Penelitian ini menggunakan pendekatan penelitian kualitatif deskriptif. Diharapkan penelitian ini dapat memberikan kontribusi dan pemikiran yang antisipatif terhadap bahaya game online bagi remaja saat ini. Kesimpulannya adalah sebagai bahan refleksi bagi orang tua, Lembaga Pendidikan, dan pemangku kepentingan dalam hubungan untuk terus menjaga generasi muda dari pengaruh buruk game online.

Kata kunci : game online, alienasi, remaja.
\end{abstract}

\section{Abstract}

The development of the internet which is increasingly advanced is the beginning of the growth of online games among teenagers. It can even be a medium that is very ertertaining and can be a part of representing a person's identity. Especially in this era, the phenomenom of teenagers who become the nation's successor has started to lose self control due to online games. The aim of this research is to critically look at the detrimental impact of online games which can alienate adolescents from the social environment and their families. This study uses a descriptive qualitative research approach. It is hoped that this research can contribute and anticipate the dangers of online games for teenagers today. The conclusion is a reflection material for parents, educational institutions, and stakeholders in the relationship to continue to protect the younger generation from the bad influence of online games.

Keywords: online games, alienation, teenager.

\section{Pendahuluan}

Game online di era globalisasi sekarang ini memang menjadi media hiburan yang begitu digemari oleh lapisan masyarakat. Bermain game online tidak mengenal umur mulai dari masa kanak-kanak, remaja, bahkan orang dewasa sekalipun ditengah rutinitas yang padat. Perkembangan jaringan internet yang kian hari kian canggih juga memicu semakin berkembangnya game online ditengah masyarakat. Bahkan mampu menjadi sebuah media yang begitu menghibur dan bisa menjadi bagian dari representasi identitas seseorang. Kemajuan media baru layaknya media sosial, mampu memberikan ruang yang seluas-luasnya bagi setiap individu untuk berkreasi dalam menampilkan identitas masing-masing. 
Membuat identitas menjadi virtual merupakan proses yang terus-menerus selayaknya proses yang terjadi di dunia nyata ( Lister, 2009:269)

Game online saat ini bahkan mampu menembus ruang dan waktu kehidupan masyarakat itu sendiri. Artinya, bermain game online bagi setiap orang tidak lagi mengenal adanya waktu kapan memulainya dan kapan harus berhenti bermain game online. Begitu juga dengan ruang (space), dimana masyarakat tidak mengenal lagi dimana mereka dapat bermain dan dimana mereka harus berhenti untuk bermain game online. Lebih mirisnya lagi di era sekarang ini, para remaja yang notabene punggawa terdepan masa depan bangsa untuk masa yang akan datang sudah mulai kehilangan kontrol dirinya akibat bermain game online.

Menilik kebelakang pada faktanya game online diciptakan sebagai media refreshing untuk remaja dan beberapa orang yang jenuh dengan rutinitas aktivitasnya yang membutuhkan media hiburan. Bermain game online begitu menyenangkan bagi sebagian orang seperti remaja dan orang-orang yang memiliki agenda aktivitas pekerjaan yang padat. Namun, sensasi menyenangkan dan hiburan yang di dapatkan dalam bermain game online, memiliki efek negatif seperti munculnya dorongan tindakan kriminalitas, timbulnya rasa ketidakpedulian terhadap lingkungan sosial sekitar, dan memicu terbentuknya perilaku sosial yang menyimpang. Hal tersebut tentunya dapat memicu lahirnya generasi muda yang mengalami krisis moral bagi remaja yang sedang dalam pencarian jati diri mereka.

Bagi remaja, sensasi bermain game online dapat menimbulkan rasa candu dalam bermain game online. Tak jarang mereka bahkan menghabiskan waktu berjam-jam di depan layar handphone dan di warung internet (warnet). Bahkan ada juga remaja yang rela sampai bolos sekolah hanya demi mengejar untuk bisa bermain game online di warnet. Bagi mereka, bermain game online merupakan cerminan dari identitas mereka atau dalam arti lain eksistensi diri seorang remaja akan terlihat jika mereka bermain game online. Tetapi, jika ini dilakukan dalam jangka waktu lama dan tanpa adanya peran dan kontrol dari orang tua dan pihak-pihak terkait, hal ini tentunya dapat membuat para remaja kehilangan kontrol dirinya dan menjerumuskan dirinya ke dalam proses alienasi (keterasingan) yang mereka buat sendiri dan menjadi pribadi yang antisosial.

Kecanduan dalam bermain game online tentunya ini akan berdampak negatif ke dalam perilaku sosial remaja itu sendiri. Dimana, pada saat usia remaja inilah proses pembentukan jati diri yang signifikan terbentuk pada seorang remaja. Maka sebab itu, perlu adanya edukasi, bimbingan, dan kontrol yang lebih dari orang tua, pendidik, dan pemerintah sebagai main rules. Melihat permasalahan 
inilah, kajian penelitian ini dibuat sebagai bahan refleksi bagi orang tua, pengajar, dan pemerintah untuk mencoba mengkaji dan menganalisis betapa bahayanya krisis moral itu jika terjadi pada remaja bangsa ini. Kita tidak tahu ke depannya nasib bangsa ini jika para generasi muda bangsa tidak memiliki bekal pengetahuan yang mempuni, tidak adanya kemampuan kontrol diri, dan banyak remaja yang antipati terhadap sesama akibat pengaruh negatif game online.

Sejatinya, para pendiri bangsa ini sejak awal kemerdekaan sudah menitipkan bangsa ini ditangan para pemuda. Maka tidak heran besarnya suatu bangsa tergantung dari besarnya peran kepedulian pemuda membangun bangsanya sebagai rasa cinta mereka terhadap bangsa dan negaranya.

\section{Metode}

Penelitian ini dilakukan pada tahun 2019 pada orang tua dan anak-anak Perumahan Grand Residence Ngemplak, Kabupaten Sukoharjo, Jawa Tengah. Metode yang digunakan di dalam penelitian ini adalah kualitatif deskriptif. Menurut Creswell (2014:4) penelitian kualitatif merupakan metode-metode untuk mengeksplorasi dan memahami makna yang oleh sejumlah individu atau sekelompok orang dianggap berasal dari masalah sosial atau kemanusiaan. Model penelitian ini yang dibatasi oleh waktu, aktivitas dan pengumpulan detail informasi dengan menggunakan berbagai prosedur pengumpulan data selama waktu tersebut (Creswell, 1994).

Alasan mengapa dipilinnya lokasi penelitian ini di kawasan perumahan Grand Residence Ngemplak, Kabupaten Sukoharjo, Jawa Tengah ini adalah karena diperumahan ini banyak sekali para remaja baik laki-laki maupun perempuan yang suka bermain "game online" dan rata-rata diperumahan ini orang tua mereka memasang internet pribadi dirumahnya (Indihome). Selain itu luasnya komplek perumahan ini ditandai dengan adanya dua kompleks perumahan grand residence (Grand residence 1 dan Grand Residence 2), membuat peneliti banyak menemukan beberapa anak-anak setiap pulang sekolah banyak bermain "game online" antar sesema mereka di halaman teras rumah mereka.

Teknik penentuan informan di dalam penelitian ini dilakukan secara purposive. Menurut Satori \& Komariah (2014:47-48) purposive sampling yaitu menentukan objek/subjek penelitian sesuai tujuan dengan menggunakan pertimbangan pribadi yang sesuai topik penelitian sebagai unit analisis dan dianggap representatif. Penelitian ini menggunakan jenis wawancara mendalam (in depth interview). Hal ini dipilih agar peneliti dapat memperoleh data yang dibutuhkan secara mendalam. Adapun teknik keabsahan data yang digunakan didalam penelitian ini adalah menggunakan teknik validasi responden dengan metode cross check ke beberapa informan di dalam penelitian ini. 


\section{Hasil dan Pembahasan}

\section{Krisis Moral Pada Generasi Muda Pecinta "Game Online"}

Di era yang modern dan globalisasi sekarang ini, kita tidak bisa menolak bahwa arus perkembangan teknologi saat ini berkembang begitu cepat diseluruh aspek kehidupan. Kita tidak bisa menampik bahwa kehidupan manusia sekarang ini tidak bisa terlepas dari peran campur tangan teknologi di dalamnya. Dahulu, di awal era millenium kita mungkin mengenal handphone sebagai alat komunikasi. Perkembangan handphone beberapa tahun terakhir berkembang begitu pesat. Handphone yang awal diproduksi untuk menunjang kehidupan manusia dalam berkomunikasi, kini telah beralih fungsi menjadi alat prestise (gengsi/kemewahan) dan sarana hiburan bagi setiap orang.

Seorang ilmuwan sosial Jean Baudrilard melihat bahwa pola konsumsi masyarakat postmodern sekarang ini tidak lagi berdasarkan nilai guna suatu barang tetapi sudah beralih kepada pengkonsumsian nilai tanda suatu barang. Masyarakat sekarang membeli handphone tidak lagi sepenuhnya digunakan sebagai alat komunikasi, tetapi mereka membeli handphone sebagai ajang pembuktian eksistensi diri mereka di masyarakat dengan asumsi bahwa memiliki handphone model terbaru dapat meningkatkan status sosial mereka di masyarakat.

Baudrillard dalam The System of Object (disarikan dari Yusuf, 2014: 176) mengemukakan bahwa satu objek untuk menjadi objek konsumsi terlebih dulu objek harus menjadi (dilihat) sebagai tanda. Memahami konsumsi adalah memahami objek sebagai serangkaian tanda-tanda sama dengan bahasa yang memerlukan penafsiran.

Ketika objek konsumsi dipelajari sebagai tanda, maka objek tidak lagi memiliki makna intrinsik yang membuatnya bermakna, karena objek dapat menghasilkan pesan-pesan sosial yang berbeda. Makna objek adalah perbedaannya dengan makna objek lain dan ini diperoleh melalui sistem objek (tanda-tanda sebagai keseluruhan Baudrillard disarikan dari Yusuf, 2014: 176).

Kebutuhan justru menjadi problematik. Kebutuhan justru menjadi psikologistik (sifat manusiawi) atau bentuk kulturalis (menjadi fungsi masyarakat). Pada masyarakat konsumer, konsumsi tidak mencari homogenisasi tapi diferensiasi (bandingkan pembuatan barang mewah secara sangat terbatas untuk kalangan elit konglomerat dunia). Yang melandasi kehidupan sosial adalah gaya hidup dan nilai, bukan kebutuhan ekonomi. Semua barang mewah yang dimiliki untuk menujukkan status, yang melandasi kehidupan sosial gaya hidup dan nilai tanda (status) dan bukan kebutuhan ekonomi (Yusuf, 2014: 179).

Pada masyarakat konsumer objek bukan saja untuk dikonsumsi, akan tetapi diproduksi lebih banyak untuk menandakan status, bukan untuk kebutuhan. Karena itu 
pada masyarakat konsumer yang lengkap, objek menjadi tanda dan lingkungan kebutuhan justru ditinggalkan (Yusuf, 2014: 179)

Begitu juga dengan para remaja sekarang ini, mereka tidak lagi melihat handphone sebagai alat komunikasi dengan orang tua, kerabat, dan temanteman terdekat mereka, melainkan mereka melihat handphone sebagai ajang eksistensi diri. Nilai guna suatu handphone sekarang sudah beralih menjadi media bermain "game online" dan juga ajang pamer bagi para remaja. Inilah awal penyebab terbentuknya krisis moral para remaja kita sekarang ini. Meleburnya batas ruang dan waktu masyarakat di era modern sekarang ini membuat para remaja kehilangan kontrol dirinya dalam penggunaan handphone untuk bermain "game online". Kemudahan dalam mengakses internet juga mempengaruhi rusaknya moral remaja bangsa kita.

Dampaknya ini semua terlihat dari banyaknya para remaja saat ini yang tidak mau peduli lagi akan pendidikannya di sekolah, tetapi fokus mereka bukan lagi bagaimana mereka bisa meningkatkan prestasi akademik mereka di sekolah dengan belajar tekun, melainkan fokus mereka adalah bagaimana mereka bisa cepat pulang kerumah agar bisa bermain "game online". Kemudian dampak lainnya dari krisis moral ini adalah menurunnya semangat belajar, hilangnya fokus untuk mengembangkan potensi diri, rusaknya psikologis sosial para remaja akibat kecanduan bermain "game online", dan yang lebih parahnya lagi ada beberapa kasus remaja yang berani menghardik orang tua mereka dengan kata-kata yang tidak pantas. Mengapa ini bisa terjadi ? menurut hemat saya, perilaku seperti ini mereka dapatkan dari lingkungan yang tidak sehat saat mereka bermain "game online". Kata-kata kotor sudah menjadi dan hal yang lumrah yang sering mereka gunakan saat bermain "game online".

Kemudian hal semacam begitu mudah di internalisasikan ke dalam diri para remaja pecandu "game online" sebagai bagian dari cerminan diri mereka. Inilah yang katakan sebagai krisis moral yang di alami oleh generasi muda bangsa ini. Dimana, generasi muda bangsa ini, tidak lagi menjadikan moral-moral ketimuran yang diajarkan pendiri bangsa ini sebagai filter diri mereka di dalam kehidupan sosialnya yang sudah dibelenggu di dalam bingkai modernisme dan globalisasi sekarang ini.

\section{Alienasi Diri yang Mengancam Generasi Muda Bangsa}

Krisis moral yang dialami para remaja saat ini kian hari semakin memprihatinkan. Miris memang melihat kondisi bangsa ini beberapa tahun ke depan jika para generasi mudanya tidak memiliki pondasi moral yang kuat. Justru, krisis moral ini membawa para generasi muda kita terjerumus ke dalam ke-alienasi-an diri mereka di tengah lingkungan sosialnya.

Berbicara Alienasi, ilmuwan sosial dan filsuf Karl Marx sudah menjelaskan 
bahwa praktek Alienasi kerap terjadi pada masyarakat industri modern di Eropa. Dimana para buruh yang bekerja di lingkungan industri saat itu ter-alienasi dari lingkungan sosialnya. Mereka terasingkan dari lingkungan sosialnya dikarenakan oleh sistem kerja produksi yang memaksa mereka untuk bekerja lebih demi menghasilkan barang produksi yang tentunya memberikan keuntungan / profit yang begitu besar bagi pemilik perusahaan.

Karl Marx membagi tiga jenis Alienasi (1) Alienasi Pekerja dari obyeknya, yakni alienasi berkaitan dengan hubungan langsung antara pekerja dengan produk yang dihasilkannya, (2) Alienasi Kepribadian, yakni alienasi yang tidak hanya berkaitan dengan hasil produksi, melainkan lebih berkaitan dengan proses produksi di dalam aktifitas produksi itu sendiri, dan (3) alienasi tenaga kerja (Maliki, 2012: 170-171).

Singkatnya, para buruh dipaksa bekerja untuk menghasilkan barang produksi demi mengejar target perusahaan. Fenomena ini membuat para buruh semakin terasingkan (Alienasi) dari lingkungan sosialnya, keluarganya, dan sesama buruh sendiri. Hal ini termasuk ke dalam alienasi pekerja seperti yang dikatakan Marx, dikarenakan fokus mereka hanya terkonsentrasikan untuk menghasilkan barang produksi sebanyakbanyak untuk perusahaan tetapi mereka di upah lebih rendah dari barang produksi yang mereka hasilkan. Melalui Alienasi pekerja telah mengubah manusia (dalam hal ini para pecandu game online) tidak menjadi manusia seutuhnya yang dapat mampu memperlakukan dirinya sebagai makhluk hidup, bersifat universal, dan memiliki kebebasan.

Para remaja pecandu "game online" telah mengubah dirinya menjadi sesuatu yang terasing di dalam lingkungan sosialnya. Keadaan seperti ini mengalienasi manusia dari tubuhnya sendiri, alam eksternal, kehidupan mental dan kehidupan manusiawinya sendiri (Maliki, 2012:173).

Memang, Marx berbicara praktek Alienasi dalam ranah industri dan produksi dengan menjadikan buruh dan pemilik modal sebagai aktornya untuk melihat praktek Alienasi. Tetapi, kali ini saya mencoba melihat praktek Alienasi dari sisi kasus yang berbeda yakni dari dampak krisis moral ini dalam ranah teknologi dan lingkungan sosial dengan para remaja sebagai aktornya. Dimana, sangat memungkinkan juga praktek Alienasi ini menjadi implikasi dari virus "krisis moral" yang mematikan bagi perkembangan kecerdasan dan wawasan generasi muda bangsa ini.

Dimana, generasi muda bangsa ini yang sejak awal sudah dipengaruhi oleh efek negatif dari "game online" sebagai pribadi yang anti-sosial dan mengalami proses kecanduan yang akut terhadap "game online". Mereka lebih senang hidup dengan dunianya sendiri tanpa memikirkan lingkungan sosial disekitar mereka. Maka, jangan disalahkan fenomena seperti ini 
akan melahirkan generasi muda yang apatis terhadap masa depan bangsa ini.

Sebagai konsekuensinya kata Marx, alienasi manusia dari produk pekerjaannya, dari aktifitas hidupnya, dan dari spesies hidup maka manusia teralienasi dari manusia yang lain dan lingkungan sosialnya. Ketika manusia melawan dirinya, berarti ia melawan orang lain. Singkatnya, manusia teralienasi dari spesies hidup, artinya setiap manusia teralienasi dari yang lain, dan setiap orang lain teralienasi dari kehidupan manusia (Maliki, 2012:174).

\section{Simpulan}

Kesimpulan yang didapatkan dari penelitian ini pertama, peran orang tua sebagai pemimpin organisasi keluarga di rumah, menjadi hal yang wajib dicermati untuk menjadi agen pengontrol sosial perkembangan pendidikan dan psikologis anak. Tidak seharusnya serta merta orang tua selalu menuruti dan menyediakan fasilitas yang memanjakan bagi sang anak yang justru membuat sang anak terjerumus ke dalam lembah "Alienasi" bagi dirinya dan tumbuh menjadi pribadi yang anti-sosial.

Kemudian, sebagai langkah strategis untuk stake holder pendidik perlu adanya pembelajaran penerapan kembali dan mendasar mengenai pemahaman nilai-nilai moral bangsa ini yang sudah tertuang di dalam ideologi "Pancasila". Pembelajaran seperti ini di sekolah tidak semestinya harus bersifat sebatas teoritis, tetapi cobalah untuk menerapkan nilai-nilai moral ini dalam ranah praktek di segala aspek lingkungan sosial, agar ke depannya proses pembentukan nilai-nilai moral dapat terinternalisasi dan menjadi bagian dari perkembangan pribadi generasi muda bangsa ini.

Terakhir, tugas pemerintah melalui Kementerian Pendidikan dan Kebudayaan (Kemendikbud) perlu adanya koordinasi dengan kementerian lainnya dan lembaga negara lainnya yang terkait untuk bisa membuat suatu terobosan kebijakan baru yang mengikat sekaligus melindungi generasi muda bangsa ini dari dampak arus globalisasi dan modern. Sebagai sedikit contoh peraturan yang mengikat sekaligus melindungi generasi muda bangsa ini dari krisis moral dampak arus globalisasi dan modern adalah seperti Pemerintah Daerah Kabupaten Bantul (D.I.Y) yang menerapkan jam belajar Masyarakat mulai dari jam 18.00-21.00 WIB.

Meskipun nantinya penerapannya ditengah jalan masih ditemukan belum sepenuhnya berjalan, tetapi itulah tugas pemerintah yang sejatinya memulainya dari nol,sesuai dengan cita-cita Presiden Kita yakni Bapak Joko Widodo (Jokowi) yakni me-revolusi mental-kan rakyatnya. Bukankah itu sesungguhnya tugas pemerintah? lya benar itulah sesungguhnya tugas pemerintah. Peraturan semacam ini bukan berarti aneh, tetapi ini sebuah langkah strategis untuk menciptakan generasi muda yang terdidik. Tidak ada salahnya, negera melalui kementeriannya untuk belajar dari peraturan-peraturan pemerintahan 
daerahnya terkait pendidikan selagi itu baik dan membangun.

\section{Ucapan Terima Kasih}

Terima kasih kepada semua pihak yang telah mendukung penulisan artikel ini. Selanjutnya kami ucapkan terima kasih kepada redaksi Jurnal Dimensia yang telah menerbitkan tulisan ini.

\section{Daftar Pustaka}

Creswell, J. W. 2014. Research Design : Pendekatan Kualitatif, Kuantitatif, dan Mixed. Yogyakarta : Pustaka Pelajar

Creswell, John H, 1994. Research Design: Qualitative and Quantitative Approaches, Sage Publication, Thousand Oaks London-New Delhi.

Lister, Martin. 2009. New Media: a critical introduction. Newyork: Routledge.

Maliki, Zainuddin.2012. Rekonstruksi Teori Sosial Modern. Yogyakarta : Gadjah Mada University Press.

Satori, D dan Komariah, A. 2014. Metodologi Penelitian Kualiatif. Bandung : Alfabeta

Yusuf, Lubis, A.2014. Postmodernisme Teori dan Metode. Jakarta : PT Raja Grafindo Persada. 